\title{
Somali Language
}

National Cancer Institute

\section{Source}

National Cancer Institute. Somali Language. NCI Thesaurus. Code C123791.

An Afroasiatic language spoken as the native language by the Somali people within the Horn of Africa. It is an official language of the Federal Republic of Somalia, a national language in Djibouti, and a working language in the Somali region of Ethiopia. 